\title{
Correlations and path analysis for fruit yield in pepper lines (Capsicum chinense L.)
}

\author{
Renato Silva Soares ${ }^{1 *}$, Hellismar Wakson da Silva ${ }^{2}$ \\ Willame dos Santos Candido', Luís Sérgio Rodrigues Vale ${ }^{3}$ \\ ISão Paulo State University, Jaboticabal, SP, Brazl \\ ${ }^{2}$ Federal University of Lavras, Lavras, MG, Brazil \\ 3Federal Institute of Goiás, Ceres, GO, Brazil \\ *Corresponding author, e-mail: renato_2366@hotmail.com
}

\begin{abstract}
Information regarding the correlation between characters are of great importance to simultaneous traits selection in breeding programs. However, quantification and interpretation of the correlations magnitude do not imply in direct and indirect effects. In this context, the path analysis is presented as an alternative and viable tool for the selection process. The objective of this study was to evaluate the phenotypic, genotypic and environmental correlations between eight major agronomic characters in pepper lines (C. chinense L.) and its consequences in direct and indirect effects by path analysis. Eight agronomic traits were assessed under field conditions in $22 \mathrm{C}$. chinense L lines. According to the results, there is a genetic variability among the evaluated lines, whose yield per plant (PY) and total number of fruits (NF) variables are highly correlated with high direct effect on pepper lines yield. The selection of pepper lines with high yield can be accomplished through direct selection or using a suitable selection index, being advantageous to select lines with other characteristics, such as appropriate scion height and diameter for conducting manual and mechanized harvesting. The use of the constant $k$ is efficient to reduce the variance of path coefficients, providing better estimation of the effects that affects yield.
\end{abstract}

Keywords: breeding, yield components, indirect selection

\section{Introduction}

The market for peppers and sweet peppers is a segment with great potential for growth both for 'in natura' consumption and for processing (Domenico et al., 2012). Estimates indicate that in the 2014 crop year Brazil produced about 75 thousand tons of Capsicum in an area of 5 thousand hectares (Reifschneider et al., 2014). However, Brazilian production is still considered low when compared to countries such as India, which produced in 20131.4 million tons of peppers and sweet peppers (FAOSTAT, 2015).

In breeding programs for pepper and sweet peppers cultivars, the main evaluated parameters are: yield, disease resistance, precocity and capsaicin content in fruits (Rodrigues et al., 2012). However, the yield is a complex character, determined by the interaction of several factors, including genetic, physiological and environmental factors (Zecevic et al., 2011). In this way, the knowledge of the correlations of other agronomic characteristics with yield, or even among them, and the environmental influence in the expression of the studied characteristics are of fundamental importance in choosing the selection strategy (Gomes et al., 2007).

The correlation analysis makes possible to analyze the magnitude and direction of 
the relations among characters, allowing to evaluate the viability of indirect selection in breeding programs, which can lead to a faster and more expressive genetic progress (Kavalco et al., 2014). Therefore, the relationships between the characters are generally evaluated through genotypic, phenotypic and environmental correlations (Nogueira et al., 2012).

Despite the usefulness of the correlation coefficient estimations for the understanding of a complex character, such as yield, these analysis do not allow to draw conclusions about the causes and effects of these relations, making impossible to know the type of association between the evaluated characters (Moreira et al ., 2013). In order to reduce these problems, Wright (1923) proposed the methodology of path analysis, which unfolds the estimated correlations in direct and indirect effects of characters on a basic variable.

The technique of path analysis has been helping breeders to develop appropriate strategies to select superior genotypes of different crops, such as sunflower (Amorim et al., 2008), maize (Entringer et al., 2014, Faria et al., 2015), soybean (Alantara et al., 2011; Nogueira et al., 2012; Perini et al., 2012), tomato (Sobreira et al., 2009; Rodrigues et al., 2010) and peppers and sweet peppers of $C$. annuum (Luitel et al., 2013, Moreira et al., 2013, Rohini \& Lakshmanan, 2015).

However, for Capsicum L. chinense peppers there is no research in literature regarding the genotype selection using correlations and path analysis. Thus, the aim of this study was to evaluate the correlations between eight main agronomic traits of pepper lines (C. chinense) and the direct and indirect effects on of the yield and its primary components by path analysis.

\section{Material and methods}

The experiment was conducted in field conditions from May, 2013 to March, 2014 at the experiment area of the Goias Federal Institute - Ceres Campus, located at -150 16 $30^{\prime \prime} \mathrm{S}$, longitude of $-49^{\circ} 35^{\prime} 54^{\prime \prime} \mathrm{W}$ and altitude of $571 \mathrm{~m}$. The climate is classified as Aw by Köppen, being tropical humid with a rainy period in summer and dry during winter.

The experimental design was a randomized block design with four repetitions. Each experimental plot consisted of a sevenmeter line, spaced one meter between plants, containing a total of seven plants per plot. Five plants were evaluated within the plot, one plant at each end being considered as border.

Twenty-two pure Cabacinha (C. chinense L.) lines were obtained by the SSD (Single Seed Descent) method for five generations of self-pollinating. in a greenhouse, according to the methodology described by Fehr (1987).

The Cabacinha type pepper has an erect growth form, orange fruits when ripe, in the shape of a gourd, and can be used in sauces and salads and is very appreciated for dishes decoration.

The seedlings were produced in expanded polystyrene trays, with 128 cells filled with commercial substrate (Plantimax $\mathrm{HT}^{\oplus}$ ), with two seeds per cell. The trays were placed on benches to seedlings production in a greenhouse. When the seedlings presented the first true leaf, thinning was performed, maintaining only the most vigorous in each cell.

The experiment was carried out in a soil with the following characteristics: $\mathrm{pH}\left(\mathrm{H}_{2} \mathrm{O}\right)=$ 6.0; $\mathrm{P}=5.0 \mathrm{mg} \mathrm{dm}^{-3} ; \mathrm{K}=100 \mathrm{mg} \mathrm{dm}^{-3} ; \mathrm{Ca}=2.34$ $\mathrm{cmolc} \mathrm{dm}^{-3} ; \mathrm{Mg}=1.27 \mathrm{cmol}_{\mathrm{c}} \mathrm{dm}^{-3} ; \mathrm{Al}=0.05 \mathrm{cmol}_{\mathrm{c}}$ $\mathrm{dm}^{-3}$ and base saturation of $50.43 \%$. Liming and fertilization were performed according to the recommendations of Filgueira (2008).

The field transplant was carried out in the first week of July 2013, when the seedlings reached between 10 and $15 \mathrm{~cm}$ in height and 4 to 6 leaves ( 45 days after sowing). The seedlings were transplanted into manually prepared pits. In each pit was placed a pepper seedling, spaced $1.0 \times 1.0 \mathrm{~m}$, between plants and between rows, respectively. Crop management was carried out according to the crop needs and to the recommendations of Filgueira (2008).

Five harvests were performed in which the characteristics were evaluated from the following descriptors: plant height $(\mathrm{PH})$, in meters, obtained by measuring from the base to the apex of the plant; Crown diameter (CD), in meters, obtained by measuring the largest diameter of the plant scion/crown; Mean yield (MY), obtained by the total mass in the plot, 
converted to $t_{\mathrm{ha}^{-1}}$; Plant productivity (PP) in $\mathrm{g}$ plant $^{-1}$, obtained by the sum of the mass of all harvests of the plot, divided by the number of evaluated plants in the plot; Total number of fruits (NF), obtained by summing the total number of fruits harvested in each plot during the harvests; Fruit length (FL), in cm; Fruit diameter (FD), in cm; Relation length/diameter of fruits (L/D). The PH and $C D$ variables were measured in three plants per plot at 150 days after transplanting. FL and FD data were obtained from the measurement of a sample of 10 fruits for each plot, using a digital caliper.

The mean values of each evaluated trait were submitted to variance analysis by the $\mathrm{F}$ test. Estimates of the genotypic $\left(r_{g e}\right)$, phenotypic $\left(r_{p h}\right)$ and environmental $\left(r_{e}\right)$ correlations were obtained for all traits combinations and it was observed the significance of the phenotypic correlations by the $T$ test. The unfolding of correlations with direct and indirect effect were performed using the path analysis (Wright, 1923), in which the mean yield was the basic variable and the other agronomic traits were considered the explanatory variables.

Estimates of the path coefficients needed to measure the direct and indirect effects of the characteristics analyzed on yield were performed under the effect of multicollinearity by using ridge path analysis, in which a constant $(k)$ is added to the diagonal elements of the Matrix $X X^{\prime} X$. The degree of multicollinearity of the $X^{\prime} X$ matrix was established based on its condition number ( $C N)$, which is the ratio of the largest to the lowest eigenvalue of the matrix (Montgomery \& Peck, 1981). The matrix eigenvalues analysis was used to identify the approximate nature of the existent linear dependence among traits, detecting those that contributed to the appearance of multicollinearity.

All statistical analysis of the present study were performed using the Genes (Cruz, 2013) software.

\section{Results and discussion}

It was observed a significant difference for all evaluated traits, with $p<0.01$ for the characteristics of PH, CD, MY, PP and NF and $\mathrm{P}$ $<0.05$ for $F L, F D$ and L/D, indicating the existence of genetic variability among the evaluated lines, which is also observed by the parameter $\mathrm{CV}$ (\%), ranging from $1.77 \%$ for FD to $26.46 \%$ for NF (Table 1). Expressive variance was also observed for pepper genotypes (C. frutescens L.), which was detected with the use of $\mathrm{CVg}$ for eight characters (Ullah et al., 2011).

Table 1. Variance analysis for plant height (PH); crown diameter (CD); Mean yield t ha-1 (MY); Productivity per plant (PP); Number of fruits per plant (NF); Fruit length (FL); Fruit diameter (FD) and fruit length/diameter ratio (L/D) of pepper lines (Capsicum chinense).

\begin{tabular}{lccccc}
\hline \multicolumn{1}{c}{ SV } & DF & \multicolumn{4}{c}{ Mean square } \\
\hline Blocks & & PH & CD & MY & PP \\
Treatments & 3 & 0.0135 & 0.029 & 28525022.2235 & 0.2846 \\
Residue & 21 & $0.0153^{* *}$ & $0.044^{* *}$ & $18298394.6650^{* *}$ & $0.1828^{* *}$ \\
\hline Mean & 63 & 0.0036 & 0.011 & 6414085.7632 & 0.0642 \\
CV (\%) & & 0.64 & 0.52 & 7276.44 & 0.73 \\
CVg & 9.34 & 21.03 & 34.81 & 34.82 \\
\hline & 8.40 & 17.59 & 23.69 & 23.65 \\
\hline Blocks & 3 & 423099.3750 & 6.7388 & 0.5635 & C/D \\
Treatments & 21 & $175076.1889^{* *}$ & $1.7253^{*}$ & $0.3726^{*}$ & $0.0231^{*}$ \\
Residue & 63 & 54454.2480 & 0.8658 & 0.1960 & 0.0112 \\
\hline Mean & & 656.19 & 25.64 & 11.86 & 2.16 \\
CV (\%) & 35.56 & 3.63 & 3.73 & 4.88 \\
CVg & 26.46 & 1.81 & 1.77 & 2.52 \\
\hline
\end{tabular}

$",=$ significant at 1 and $5 \%$ of probability, respectively, according to the F test. CV (\%): coefficient of variation; CVg: genetic coefficient of variation.

The coefficients of experimental variation of the present study presented magnitudes ranging from $3.63 \%$ for $\mathrm{FL}$ to $35.56 \%$ for NF. High evidenced the complex nature of these characteristics, which has complex genetic control, with presence of dominant genes and $\mathrm{CV}$ values for MY, PP and NF characteristics epistatic effects, as well as the existence of 
reduced restricted heritability, indicating strong influence of the environment on the evaluated traits (Rêgo et al., 2009).

The phenotypic correlation estimates were positive and significant by the T test among PH and CD (0.8337), MY (0.676), PP (0.6761) and NF (0.7271). The correlations between CD and the characters MY, PP and NF were positive and significant $(0.8216,0.822$ and 0.8508 , respectively). The MY trait presented high positive correlation (above 0.7) (Nogueira et al., 2012) and significant with the characteristic PP (1.00) and NF (0.9843), but these correlations were already expected, since the MY and NF characteristics were used. The same was observed for the correlation between PP and NF (0.9843), COMP and L/D (0.6753). Significant phenotypic correlations, with negative values, were observed between the characters CD x FL $(-0.4443)$, MY X FL $(-0.4743)$ and L/D (-0.4201), PPxFL (-0.4727), NF x FL (-0.4991), FD $x \mathrm{~L} / \mathrm{D}(-0.6812)$ (Table 2).

Table 2. Estimation for the phenotypic $\left(r_{p h}\right)$, genotypic $\left(r_{g e}\right)$ and environmental $\left(r_{e}\right)$ coefficients of eight agronomic characters in 22 pepper lines (Capsicum chinense L.)

\begin{tabular}{|c|c|c|c|c|c|c|c|c|}
\hline Variables & & $C D$ & MY & PP & NF & $\mathrm{FL}$ & FD & $L / D$ \\
\hline \multirow[t]{3}{*}{$\mathrm{PH}$} & $r_{p h}$ & $0.8337^{* *}$ & $0.6760^{* *}$ & $0.6761^{* *}$ & $0.7271^{* *}$ & -0.4146 & -0.2767 & -0.0917 \\
\hline & $r_{g e}$ & 0.9864 & 0.7491 & 0.7494 & 0.8326 & -0.6907 & -0.3690 & -0.1483 \\
\hline & $r_{e}$ & 0.4283 & 0.5517 & 0.5517 & 0.5400 & -0.1622 & -0.1785 & -0.0044 \\
\hline \multirow[t]{3}{*}{$C D$} & $r_{p h}$ & & $0.8216^{* *}$ & $0.8220^{* *}$ & $0.8508^{* *}$ & $-0.4443^{*}$ & -0.1801 & -0.1843 \\
\hline & $r_{g e}$ & & 0.8936 & 0.8944 & 0.9384 & -0.5804 & -0.1902 & -0.2058 \\
\hline & $r_{e}$ & & 0.7032 & 0.7032 & 0.7038 & -0.3630 & -0.1860 & -0.1620. \\
\hline \multirow[t]{3}{*}{$M Y$} & $r_{p h}$ & & & $1.0000^{* *}$ & $0.9843^{* *}$ & $-0.4743^{*}$ & 0.1111 & $-0.4201^{*}$ \\
\hline & $r_{g e}$ & & & 1.0000 & 0.9903 & -0.7657 & 0.4054 & -0.7211 \\
\hline & $r_{e}$ & & & 1.0000 & 0.9755 & -0.2487 & -0.1948 & -0.0580 \\
\hline \multirow[t]{3}{*}{ PP } & $r_{p h}$ & & & & $0.9843^{* *}$ & $-0.4727^{*}$ & 0.1106 & -0.4187 \\
\hline & $r_{g e}$ & & & & 0.9905 & -0.7641 & 0.4062 & -0.7210 \\
\hline & $r_{e}$ & & & & 0.9753 & -0.2471 & -0.1961 & -0.0556 \\
\hline \multirow[t]{3}{*}{ NF } & $r_{p h}$ & & & & & $-0.4991^{*}$ & 0.0209 & -0.3723 \\
\hline & $r_{\mathrm{ge}}$ & & & & & -0.7157 & 0.2834 & -0.6099 \\
\hline & $r_{e}$ & & & & & -0.3407 & -0.2534 & -0.0877 \\
\hline \multirow[t]{3}{*}{$\mathrm{FL}$} & $r_{p h}$ & & & & & & 0.0784 & $0.6753^{* *}$ \\
\hline & $r_{g e}$ & & & & & & -0.1884 & 0.7269 \\
\hline & $r_{e}$ & & & & & & 0.2463 & 0.6532 \\
\hline \multirow[t]{3}{*}{ FD } & $r_{p h}$ & & & & & & & $-0.6812^{* *}$ \\
\hline & $r_{g e}$ & & & & & & & -0.8112 \\
\hline & $r_{e}$ & & & & & & & -0.5713 \\
\hline
\end{tabular}

'Plant height (PH); crown diameter (CD); mean yield $t \mathrm{ha}^{-1}$ (MY); plant productivity (PP); number of fruits per plant (NF); fruit length (FL); fruit diameter (FD) and fruit length/diameter ratio (L/D). ", ": significant at 1 and $5 \%$, for the $t$ test, respectively.

In plant breeding programs, it is important to know the relations between agronomic traits, since they can positively contribute to a better selection for production. In the present study, it is possible to verify some important correlations between the evaluated traits, aiming at more productive plants, as observed between the characteristic $\mathrm{Ph} \times \mathrm{Cd}$ and $\mathrm{NF}$, as well as $\mathrm{CD} \times$ MY, PP and NF

Similar results were observed by Luitel et al. (2013), when studying a segregant population of Capsicum annuum L., observing the correlation and path analysis for yield and fruit quality, verified a positive and significant correlation between the number of fruits per plant and total production, Fruit length and L/D ratio, and negative for L/D and fruit diameter. Shrestha et al. (2010) reported a positive correlation between the number of fruits, fruit weight and yield of sweet pepper fruits. The genotypic correlations, except between FL $x$ FD, were all higher than the phenotypic correlations, evidencing that the phenotype is influenced in greater magnitude by the genetic portion of the trait, which may favor the indirect selection of the traits. Rohini \& Lakshmanan (2015) reported using correlation and path analysis for pepper production study, for all evaluatedl traits, that the genotype correlation coefficient was superior than the phenotype, corroborating with the results obtained in the present study.

As for the phenotypic correlations, the 
genotypic correlations, oh higher magnitudes, it was observed between the pairs PHXCD (0.9864), NF (0.8326), PP (0.7494) and MY $(0.7491)$; CDXMY (0.8936), PP (0.8944) and NF (0.9384); MY XPP (1.0) and NF (0.9903); PP x NF (0.9905); FL x L/D (0.7269) (Table 2).

Thus, the identification of the correlation between easy-to-measure characteristic and productivity-related characteristics is one of the objectives of the breeding programs to facilitate and accelerate the selection of superior plants (Oliveira et al., 2010).

Yadeta et al. (2011) found a positive and significant phenotypic correlation between fruit production (Capsicum annuum L.) and fruit length (0.537), fruit weight $(0.616)$ and fruit diameter (0.647). In the study performed by Ullah et al. (0.622), fruit diameter (0.362) and plant height (0.073) were significantly associated with the number of fruits per plant (0.622), similar to the observed in this present study.

Mean to high genotype correlations (above 0.7) (Nogueira et al., 2012), with negative values were observed for the characters $\mathrm{PH} \times \mathrm{FL}$ (-0.6907), CDxFL (-0.5804), MYXFL (-0.7657) and L/D (-0.7211), PP x FL (-0.7641) and L/D (-0.721), NF $x F L(-0.7157)$ and $L / D(-0.6099), F D \times L / D(-0.8112)$ (Table 2).

Evaluating all studied traits, it is possible to affirm that the MY variable present more relevant economic importance, since for breeding programs it is important the selection of plants with high productivity and with fruits of good market standard. It is verified, however, that most explanatory variables are correlated, demonstrating how complex the relationship between the characteristics related to MY is. The unfolding of the main correlations in direct and indirect effects is important to evaluate the magnitude of the relation of the explanatory variables to the main one.

The multicollinearity analysis revealed that the evaluated correlations presented a number of variance inflation factors (VIF) above 10 and a condition number (CN) of 1471.17 for all variables, characterizing the existence of severe colinearity (Montgomery \& Peck, 1981). This result does not impairs the path analysis performance, since there are already appropriate methodologies for studying direct and indirect effects under multicollinearity (Carvalho et al., 1999; Coimbra et al., 2005).

To circumvent multicollinearity, it was used the methodology proposed by Carvalho (1999), called Crest Path Analysis, in which a constant $(k)$ is added to the diagonal elements of the X'X matrix. The $k$ value is the smallest value able to stabilize most of the estimators of the path coefficients. In this way, the value of $k=0.05$ was used (Carvalho et al., 1999; Amorim et al., 2008; Moreira et al., 2013) correcting the distortions and all variables used, in general, FV values less than 10 , leading to greater reliability in the cause and effect interpretations among the studied characters.

The coefficient of determination of the path analysis $\left(\mathrm{R}^{2}\right)$ was 0.9708 , characterizing that $97.08 \%$ of the variation of the MY dependent variable in the model is explained by the effect of the studied variables (Table 3).

Although the study of simple correlations showed that the variables PP (1.00), NF (0.9843), and $C D(0.8216)$ were the most relevant to increase productivity, there was a high correlation between MY and CD (0.8216), does not meaning the cause and effect relationship between these variables, that is, the selection of genotypes with high MY by direct response of CD, would not be efficient, since PP and NF is the variables with high direct effects on PD. According to Cruz \& Carneiro (2006), high correlation and low direct effect is an indication that the best strategy to provide satisfactory gains in the main variable is the simultaneous selection of the variables, with emphasis also on those whose indirect effects are significant.

Considering the direct effects on yield, it can be observed that the MY (0.5536) and NF (0.3672) presented the highest direct effects and total correlations, demonstrating a good combination between the path coefficient and or phenotypic correlation, indicating a large contribution of these characters to increase yield (Table 3).

Similar results were observed by Farhad et al. (2008), in which the number of fruits per plant was the variable with a great direct effect on the C. annuum (0.8513) yield. 
Table 3. Estimation of the direct and indirect effects of the production character ( $\mathrm{kg} \mathrm{ha}^{-1}$ ) on pepper (Capsicum chinense L.) and its primary components - plant height (PH); crown diameter (CD); Productivity per plant (PP); Number of fruits per plant (NF); Fruit length (FL); Fruit diameter (FD) and fruit length/ diameter ratio (L/ D)

\begin{tabular}{|c|c|c|}
\hline Characteristics & Estimated Correlation & VIF \\
\hline \multicolumn{3}{|l|}{ Plant height } \\
\hline Direct effect on MY & -0.0047 & 3.1099 \\
\hline Indirect effect via CD & 0.0501 & 2.8959 \\
\hline Indirect effect via PP & 0.3743 & 3.8732 \\
\hline Indirect effect via NF & 0.2670 & 4.7750 \\
\hline Indirect effect via FL & -0.0017 & 0.9701 \\
\hline Indirect effect via FD & -0.0104 & 0.4319 \\
\hline Indirect effect via L/D & 0.0016 & 0.0781 \\
\hline Total & 0.676 & \\
\hline \multicolumn{3}{|l|}{ Crown diameter } \\
\hline Direct effect on MY & 0.0602 & 3.1099 \\
\hline Indirect effect via PH & -0.0039 & 2.8959 \\
\hline Indirect effect via PP & 0.4551 & 3.8732 \\
\hline Indirect effect via NF & 0.3124 & 4.7751 \\
\hline Indirect effect via FL & -0.0018 & 0.9701 \\
\hline Indirect effect via FD & -0.0068 & 0.4319 \\
\hline Indirect effect via L/D & 0.0032 & 0.0781 \\
\hline Total & 0.8216 & \\
\hline \multicolumn{3}{|l|}{ Plant productivity } \\
\hline Direct effect on MY & 0.5536 & 9.3876 \\
\hline Indirect effect via PH & -0.0032 & 1.2831 \\
\hline Indirect effect via CD & 0.0495 & 2.8152 \\
\hline Indirect effect via NF & 0.3615 & 8.7499 \\
\hline Indirect effect via FL & -0.0019 & 1.2607 \\
\hline Indirect effect via FD & 0.0042 & 0.0688 \\
\hline Indirect effect via L/D & 0.0073 & 1.6300 \\
\hline Total & 1 & \\
\hline \multicolumn{3}{|l|}{ Number of fruits per plant } \\
\hline Direct effect on MY & 0.3672 & 10.0062 \\
\hline Indirect effect via PH & -0.0034 & 1.4841 \\
\hline Indirect effect via CD & 0.0511 & 3.0159 \\
\hline Indirect effect via PP & 0.5449 & 8.2089 \\
\hline Indirect effect via FL & -0.0020 & 1.4058 \\
\hline Indirect effect via FD & 0.0008 & 0.0022 \\
\hline Indirect effect via L/D & 0.0065 & 1.2888 \\
\hline Total & 0.9843 & \\
\hline \multicolumn{3}{|l|}{ Fruit length } \\
\hline Direct effect on MY & 0.0041 & 6.2524 \\
\hline Indirect effect via PH & 0.0019 & 0.4825 \\
\hline Indirect effect via CD & -0.0267 & 0.8224 \\
\hline Indirect effect via PP & -0.2617 & 1.8929 \\
\hline Indirect effect via NF & -0.1833 & 2.2498 \\
\hline Indirect effect via FD & 0.0029 & 0.0344 \\
\hline Indirect effect via L/D & -0.0118 & 4.2402 \\
\hline Total & -0.4743 & \\
\hline \multicolumn{3}{|l|}{ Fruit diameter } \\
\hline Direct effect on MY & 0.0376 & 6.2479 \\
\hline Indirect effect via PH & 0.0013 & 0.2150 \\
\hline Indirect effect via CD & -0.0108 & 0.1349 \\
\hline Indirect effect via PP & 0.0612 & 0.1034 \\
\hline Indirect effect via NF & 0.0077 & 0.0036 \\
\hline Indirect effect via FL & 0.0003 & 0.0344 \\
\hline Indirect effect via L/D & 0.0119 & 4.3146 \\
\hline Total & 0.1111 & \\
\hline \multicolumn{3}{|l|}{ Fruit length/ diameter } \\
\hline Direct effect on MY & -0.0175 & 10.3019 \\
\hline Indirect effect via $\mathrm{PH}$ & 0.0004 & 0.0236 \\
\hline Indirect effect via CD & -0.0111 & 0.1416 \\
\hline Indirect effect via PP & -0.2318 & 1.4854 \\
\hline Indirect effect via NF & -0.1367 & 1.2518 \\
\hline Indirect effect via FL & 0.0028 & 2.5734 \\
\hline Indirect effect via FD & -0.0256 & 2.6167 \\
\hline Total & -0.4201 & \\
\hline Coefficient of determination & 0.9709 & \\
\hline$k$ value used in the analysis & 0.05 & \\
\hline Effect of the residual variable & 0.1706 & \\
\hline
\end{tabular}

Krishnamurthy et al. (2013) also verified direct and positive effects of the variable fruits per plant (0.819) on the yield of green pepper fruits (C. annuum L.), followed by fruit length (0.311), fruit width (0.243) and production of red fruits (0.215).
In breeding programs it is important to identify, among the variables of high correlation with the basic variable, those with a greater direct effect favoring the selection, so the correlated response through indirect selection is efficient (Cruz et al., 2004). 
For indirect effects via PY, it is observed in the present study (Table 3 ) that the correlation coefficients for PH (0.3742), CD (0.4550) and NF (0.5449) were positive, which implies a correlation of characters in equal directions, where the increase of one reflects on the increase of the other, thus, with the PY character, is possible to predict a satisfactory gain for simultaneous selection.

For FL $(-0.2616)$ and L/D $(-0.2317)$ there was a trend of correlation with negative values, where the increase of one implies on the reduction of the other. The negative value of $\mathrm{FL}$ are not in accordance with the results obtained by Moreira et al. (2013), while for the L/D ratio, similar results were observed. Similar observation can be made for indirect effects via NF with the traits $\mathrm{PH}(0.2670), \mathrm{CD}(0.3124)$ and $\mathrm{PF}(0.3614)$ with positive values, whereas for FL $(-0.1832)$ and $L / D$ $(-0.1367)$ negative values were observed.

Studying yellow pepper (C. annuum L.), Maga et al. (2013) verified positive direct effect of the number of fruits per plant (0.91) and fruit weight (0.28) on fruit yield, while fruit diameter $(-0.2)$ and plant height ( -0.2) showed negative direct effect. The indirect effects were positive values of leaf number, fruit weight and number of fruits per plant on production, corroborating with the results obtained in the present study.

Luitel et al. (2013) verified by path analysis a positive direct effect of the characters fruit production per plant, length, weigth and pericarp thickness on the total production and a direct negative effect of the fruit diameter on production.

In general, the indirect selection among primary components of yield (MY) seems to be a good strategy for genetic progress in the most important primary character, since most of the indirect effects are positive. However, for the direct effect, the PP and NF characters allow the direct selection to increase MY.

The primary variables that contributed the most to the increase in MY were PP, NF, CD and $\mathrm{PH}$, respectively, with $\mathrm{PP}, \mathrm{NF}$ and $\mathrm{CD}$ contributing directly and indirectly and $\mathrm{PH}$ contributing indirectly (Table 3), which demonstrates the potential use of these characters in the MY selection process.

\section{Conclusions}

The selection of pepper lines with high yield can be directly performed through the variables PP and NF, since they showed high correlation and high direct effect on pepper lines yield.

The use of the $k$ constant showed to be efficient to reduce the variance of the path coefficients, providing a better estimation of the effects that affect yield.

\section{References}

Alcantara Neto, F., Gravina, G.A., Monteiro, M.M.S., Morais, F.B., Petter, F.A., Albuquerque, J.A.A. 2011 . Análise de trilha do rendimento de grãos de soja na microrregião do Alto Médio Gurguéia. Comunicata Scientiae 2: 107-112.

Amorim, E.P., Ramos, N.P., Ungaro, M.R.G., Kiihl, T.A.M. 2008. Correlações e análise de trilha em girassol. Bragantia 67: 307-316.

Carvalho, C.G.P., Oliveira, V.R., Cruz, C.D., Casali, V.W.D. 1999. Análise de trilha sob multicolinearidade em pimentão. Pesquisa Agropecuária Brasileira 34: 603-613.

Coimbra, J.L.M., Benin, G., Vieira, E.A., Oliveira, A.C. de, Carvalho, F.I.F., Guidolin, A.F., Soares, A.P. 2005. Consequências da multicolinearidade sobre a análise de trilha em canola. Ciência Rural 35: 347-352.

Cruz, C.D., Carneiro, P.C.S. 2006. Modelos biométricos aplicados ao melhoramento genético. Editora UFV, Viçosa, Brasil. 585 p.

Cruz, C.D., Regazzi, A.J., Carneiro, P.C.S. 2004. Modelos biométricos aplicados ao melhoramento genético (3 ed.) Editora UFV, Viçosa, Brasil. 480 p.

Cruz, C.D. 2013. GENES - a software package for analysis in experimental statistics and quantitative genetics. Acta Scientiarum Agronomy 35: 271276.

Domenico, C.I., Coutinho, J.P., Godoy, H.T., Melo, A.M.T. 2012. Caracterização agronômica e pungência em pimenta de cheiro. Horticultura Brasileira 30: 466-472.

Entringer, G.C., Santos, P.H.A.D., Vettorazzi, J.C.F., Cunha, K.S.C., Pereira, M.G. 2014. Correlação e análise de trilha para componentes de produção de milho superdoce. Revista Ceres 61: 356-361.

Farhad, M., Hasanuzzaman, M., Biswas, B.K., Azad, A.K., Arifuzzaman, M. 2008. Reliability of yield contributing characters for improving yield potential in chilli (Capsicum annuum). 
International Journal of Sustainable Crop Production 3: 30-38.

FAOSTAT. Food and Agriculture Organization of the United Nations. 2015. http://faostat3.fao.org/ download/Q/QC/E <Acesso em 25 Set. 2015>

Faria, L.A., Pelúzio, J.M., Afférri, F.S., Carvalho, E.V., Dotto, M.A., Faria, E.A. 2015. Path analysis for growth and grain yield of corn genotypes under different nitrogen doses. Journal of Bioenergy and Food Science 2: 1-11.

Fehr, W.R. 1987. Principles of cultivar development. Theory and techinique. Macmillan Publishing Company, New York, USA, 536 p.

Filgueira, F.A.R. 2008. Novo manual de olericultura. Editora UFV, Viçosa, Brasil, 421 p.

Gomes, C.N.; Carvalho, S.P.; Jesus, A.M.S., Custódio, T.N. 2007. Caracterização morfoagronômica e coeficientes de trilha de caracteres componentes da produção em mandioca. Pesquisa Agropecuária Brasileira 42: 1121-1130.

Kavalco, S.A.F., Figueiredo, R., Groli, E.L., Zimmer, C.M., Baretta, D., Tessmann, E.W., Júnior, A.M.M., Oliveira, A.C. 2014. Análise de trilha em genótipos de trigo submetidos ao estresse por encharcamento. Semina 35: 1683-1696.

Krishnamurthy, S.L., Madhavi Reddy, K., Mohan Rao, A. 2013. Genetic variation, path and correlation analysis in crosses among Indian and Taiwan parents in chilli. Vegetable Science 40: 210-213.

Luitel, B.P., Yoon, C.S., Kang, W.H. 2013. Correlation and path coefficient analysis for fruit yield and quality characters in segregating population of mini-paprika (Capsicum annuum L.). Journal of Agricultural, Life and Environmental Sciences 25: 1-7.

Maga, T.J., Uguru, M.I., Ogbonna, P.E. 2013. Variability and Association Studies on Yield and Yield Characters in Aromatic Nsukka Yellow Pepper (Capsicum annuum L.). International Journal of Plant Breeding 7: 90-95.

Montgomery, D.C., Peck, E.A. 1981. Introduction to linear regression analysis. Wile oline library, New York, USA, 504 p.

Moreira, S.O., Gonçalves, L.S.A., Rodrigues, R.R., Sudré, C.P., Júnior, A.T.A., Medeiros, A.M. 2013. Correlações e análise de trilha sob multicolinearidade em linhas recombinadas de pimenta (Capsicum annuum L.). Revista Brasileira de Ciências Agrárias 8: 15-20.

Nogueira, A.P.O., Sediyama, T., Sousa, L.B., Hamawaki, O.T., Cruz, C.D., Pereira, D.G., Matsuo,
E. 2012. Análise de trilha e correlações entre caracteres em soja cultivada em duas épocas de semeadura. Bioscience Journal 28: 877-888.

Oliveira, E.J. de, Lima, D.S. de, Lucena, R.S., Motta, T.B.N., Dantas, J.L.L. 2010. Correlações genéticas e análise de trilha para número de frutos comerciais por planta em mamoeiro. Pesquisa Agropecuária Brasileira 45: 855-862.

Perini, L.J., Júnior, N.S.F., Destro, D., Prete, C.E.C. 2012. Componentes da produção em cultivares de soja com crescimento determinado e indeterminado Semina: Ciências Agrárias 33: 2531-2544.

Reifschneider, F.J.B., Nass, L.L., Henz, G.P. 2014. Uma pitada de biodiversidade na mesa dos brasileiros ( $1^{\mathrm{a}}$ ed). Brasília-DF, $156 \mathrm{p}$.

Rêgo, E.R., Rêgo, M.M., Finger, F.L., Cruz, C.D., Casali, V.W.D. 2009. A diallel study of yield components and fruit quality in chilli pepper (Capsicum baccatum). Euphytica 168: 275-287.

Rodrigues, G.B., Marim, B.G., Silva, D.J.H., Mattedi, A.P., Almeida, V.S. 2010. Análise de trilha de componentes de produção primários e secundários em tomateiro do grupo Salada. Pesquisa agropecuária brasileira 45: 155-162.

Rodrigues, R., Gonçalves, L.S.A., Bento, C.S., Robaina, R.R., Sudré, C.P., Amaral Júnior, A.T. 2012. Combining ability and heterosis for agronomic traits in chili pepper. Horticultura Brasileira 30: 226-233.

Rohini, N., Lakshmanan, V. 2015. Correlation and path coefficient analysis in chilli for yield and yield attributing traits. Journal of Applied and Natural Sciences 4: 25-32.

Shrestha, S.L., Luitel, B.P., Lee, T.J., Kang, W.H. 2010. Fruit yield and quality evaluation of sweet pepper (Capsicum annuum L.) Fl hybrids derived from inbred lines. Korean Journal of Breeding Science 42: 344-350.

Sobreira, F.M., Sobreira, F.M., Fialho, G.S., Sánchez, C.F.B., Matta, F.P. 2009. Análise de trilha em póscolheita de tomate tipo salada. Revista Facultad Nacional de Agronomía Medellín 62: 4983-4988

Ullah, M.Z., Hasan, M.J., Saki, A.I., Rahman, A.H.M.A., Biswas, P.L. 2011 Association of correlation and cause-effect analysis among morphological traits in chili (Capsicum frutescens L.). International Journal of Biological Research 10: 19-24.

Wright, S. 1923. The theory of path coefficients a reply to nile's criticism. Genetics 8: 239-255. 
Yadeta, B., Belew, D., Gebreselassie, W., Marame, F. 2011. Genetic association among seme atributes of hot pepper (Capsicum annuum L.) genotypes in West Shoa, Ethiopia. Middle-East Journal of Scientific Research 7: 567-573.

Zecevic, B., Dordevic, R., Balkaya, A., Damnjanovic, J., Dordevic, M., Vujosevic, A. 2011. Influence of parental germplasm for fruit characters in F1, F2 and F3 generations of pepper (Capsicum annuum L.). Genetika 43: 209-216. 